\title{
Isolation and Characterization of a New Cyanobacterial Strain with a Unique Fatty Acid Composition
}

\author{
Fariza K. Sarsekeyeva',2, Aizhan A. Usserbaeva'2, Bolatkhan K. Zayadan'2, Kirill S. Mironov', \\ Roman A. Sidorov', Anna Yu. Kozlova1, Elena V. Kupriyanova1, Maria A. Sinetova1, \\ Dmitry A. Los $^{1^{*}}$ \\ ${ }^{1}$ Institute of Plant Physiology, Russian Academy of Sciences, Moscow, Russia \\ ${ }^{2}$ Department of Biotechnology, Faculty of Biology and Biotechnology, Al-Farabi Kazakh National University, \\ Almaty, Kazakhstan \\ Email: $\underline{\text { *osda@ippras.ru }}$
}

Received 9 September 2014; revised 21 October 2014; accepted 3 November 2014

Copyright $@ 2014$ by authors and Scientific Research Publishing Inc.

This work is licensed under the Creative Commons Attribution International License (CC BY). http://creativecommons.org/licenses/by/4.0/

(c) () Open Access

\begin{abstract}
A new cyanobacterial strain was isolated and purified from salt Lake Balkhash, Kazakhstan. According to its morphological and ultrastructural characteristics, 16S rRNA sequence and the fatty acid profile, the strain has been classified as Cyanobacterium spp. and assigned as Cyanobacterium sp. IPPAS B-1200. The strain is characterized by a non-temperature inducible $\Delta 9$-desaturation system, and by high relative amounts of myristic (14:0-30\%) and myristoleic (14:1 $\Delta 9-10 \%)$ acids. The total amount of $\mathrm{C}_{14}$ fatty acids reaches $40 \%$, which is unusually high for cyanobacteria, and it has never been reported before. The remaining fatty acids are represented mainly by palmitic (16:0) and palmitoleic (16:1 $\Delta 9$ ) acids (the sum reaches nearly $60 \%)$. Such a fatty acid composition, together with a relatively high speed of growth, makes this newly isolated strain a prospective candidate for biodiesel production.
\end{abstract}

\section{Keywords}

Cyanobacterium, Fatty Acids, Lake Balkhash, Myristic Acid, Myristoleic Acid, 16S rRNA

\section{Introduction}

Cyanobacteria (formerly blue-green algae) are considered as one of the most ancient group of living organisms

"Corresponding author.

How to cite this paper: Sarsekeyeva, F.K., Usserbaeva, A.A., Zayadan, B.K., Mironov, K.S., Sidorov, R.A., Kozlova, A.Yu., Kupriyanova, E.V., Sinetova, M.A. and Los, D.A. (2014) Isolation and Characterization of a New Cyanobacterial Strain with a Unique Fatty Acid Composition. Advances in Microbiology, 4, 1033-1043. http://dx.doi.org/10.4236/aim.2014.415114 
on Earth [1]. Different species of modern cyanobacteria inhabit almost all environments-from soil to fresh and sea waters, as well as such extreme habitats as hot springs, soda and salt lakes, etc. Cyanobacteria, which are characterized by rapid photoautotrophic growth and high speed of biomass accumulation, are now considered as important renewable energy alternatives for petroleum-based fuels, i.e. biofuels — biogas [2], bioethanol [3] [4] butanol [5], or biodiesel [6].

Biodiesel is produced by trans-esterification of plant oils, yielding fatty acid methyl or ethyl esters. Such production depends on the availability of vegetable oil feedstock. $\mathrm{CO}_{2}$-fixing and oil-producing eukaryotic algae might be another source to produce biodiesel. However, there are still technological barriers and economic issues that hamper the industrial development of high-yield oil-producing algal strains [7]. Cyanobacteria have several advantages in comparison to higher plants and algae: 1) they grow much faster than competitors; 2) they have high photosynthetic efficiency; 3 ) they are transformable by double homologous recombination. The latter allows targeted mutagenesis and genetic transformation that imply full-scale metabolic design and engineering of organisms that efficiently convert solar energy into high-value products [8].

Cyanobacteria usually do not store fatty acids (FAs) in the form of triacylglycerides. The majority of their FAs are a part of diacylglycerides of the membrane lipids. According to fatty acid composition, all cyanobacteria have been divided into four groups [9]. Organisms in Group 1 (mainly representatives of mesophilic and thermophilic Synechococcus) introduce only one double bond at the $\Delta 9$ position of fatty acids (usually $\mathrm{C}_{16}$ or $\mathrm{C}_{18}$ FAs) at the $s n-l$ position. In cyanobacteria of Group 2 (Anabaena, Nostoc, Gloeobacter violaceus, etc.), the $\mathrm{C}_{18}$ acid is desaturated at the $\Delta 9, \Delta 12$, and $\Delta 15$ positions and the $\mathrm{C}_{16}$ acid is desaturated at the $\Delta 9$ and $\Delta 12$ positions. In Group 3 (Spirulina or Arthrospira strains), the $\mathrm{C}_{18}$ acid is desaturated at the $\Delta 6, \Delta 9$, and $\Delta 12$ positions. Finally, in Group 4 (model strain Synechocystis sp. PCC 6803), the $\mathrm{C}_{18}$ stearic acid is desaturated at the $\Delta 6, \Delta 9, \Delta 12$, and $\Delta 15$ positions. The $\mathrm{C}_{16}$ palmitic acid is not desaturated in Groups 3 and 4 [9].

Resent advances in sequencing techniques allow determination of the whole genomes of various cyanobacterial strains. Genes for specific fatty acid desaturases have been identified, and they raise the need of an update to the previously postulated FA-based classification of cyanobacteria. Now, at least, one additional group of cyanobacteria should be allocated, in which $\mathrm{C}_{18}$ and $\mathrm{C}_{16}$ fatty acids are desaturated at positions $\Delta 9$ and $\Delta 12$. The organisms in this group are represented by marine species of Prochlorococcus and Synechococcus [10], and they can produce dienoic fatty acids.

Control of FAs carbon chain length provides a mechanism to generate biofuels with specified properties, since $\mathrm{C}_{10-14} \mathrm{FAs}$ may be used as components of jet biofuels, whereas $\mathrm{C}_{16-18}$ FAs may be employed for biodiesel production [11]. So far, $\mathrm{C}_{10-12}$ FAs of cyanobacteria have been found in significant amounts (at $50 \%$ of the total FAs of Trichodesmium erythraeum grown in laboratory conditions) in an early report [12]. However, their abundant presence has not been confirmed in the same strain grown in natural environment [13]. $\mathrm{C}_{14}$ FAs have been reported in significant amounts in several strains: 14:0 in Trichodesmium erythraeum [11] [12] or Phormidium J-1 [14]; 14:0 and 14:1 in Prochlorothrix hollandica (up to 30\%) [15]. The latter strain, however, is rather capricious and problematic for mass cultivation.

Here we report the isolation and partial characterization of a new strain, which belongs to cyanobacteria of Group 1 [9], and produces $40 \%$ of medium-chain $\mathrm{C}_{14}$ FAs together with nearly $60 \%$ of $\mathrm{C}_{16}$ FAs. This strain can efficiently grow in a wide range of temperatures. These unique characteristics put this cyanobacterium into a line of the potential producers of biofuels.

\section{Materials and Methods}

\subsection{Collection, Purification, and Growth of Cyanobacterial Strain}

Samples of cyanobacteria were from the Bay Kurta, Lake Balkhash, Republic of Kazakhstan $\left(46^{\circ} 32^{\prime} 27^{\prime \prime}\right.$ North latitude, 74 $52^{\prime} 44^{\prime \prime}$ East longitude). Samples were collected in October 2013, when water temperature on the surface was $15^{\circ} \mathrm{C}-17^{\circ} \mathrm{C}$, and salinity of water was $6 \mathrm{~g} \cdot l^{-1}$. The area of Lake Balkhash is $18,200 \mathrm{~km}^{2}$; it is situated $342 \mathrm{~m}$ above sea level. For isolation and cultivation of the strains, standard methods were used. Algologically pure and axenic cultures were obtained by dilutions and plating on Zarrouk medium [16] [17], which was prepared as follows $\left(\mathrm{g} \cdot \mathrm{l}^{-1}\right): \mathrm{NaHCO}_{3}-16.8 ; \mathrm{K}_{2} \mathrm{HPO}_{4} \times 3 \mathrm{H}_{2} \mathrm{O}-1 ; \mathrm{NaNO}_{3}-2.5 ; \mathrm{K}_{2} \mathrm{SO}_{4}-1 ; \mathrm{NaCl}-1.0 ; \mathrm{MgSO}_{4}$ $\times 7 \mathrm{H}_{2} \mathrm{O}-0.2 ; \mathrm{CaCl}_{2} \times 2 \mathrm{H}_{2} \mathrm{O}-0.027$. Microelements №1 at $1 \mathrm{ml} \cdot \mathrm{l}^{-1}\left(\mathrm{~g} \cdot \mathrm{l}^{-1}\right): \mathrm{H}_{3} \mathrm{BO}_{3}-2.86 ; \mathrm{MnCl}_{2} \times 4 \mathrm{H}_{2} \mathrm{O}-1.81$; $\mathrm{ZnSO}_{4} \times 7 \mathrm{H}_{2} \mathrm{O}-0.22 ; \mathrm{CuSO}_{4} \times 5 \mathrm{H}_{2} \mathrm{O}-0.08 ; \mathrm{MoO}_{3}-0.015$. Microelements №2 at $1 \mathrm{ml} \cdot \mathrm{l}^{-1}\left(\mathrm{~g} \cdot \mathrm{l}^{-1}\right): \mathrm{NH}_{4} \mathrm{VO}_{3}-$ $0.023 ; \mathrm{K}_{2} \mathrm{Cr}_{2}\left(\mathrm{SO}_{4}\right)_{4} \times 24 \mathrm{H}_{2} \mathrm{O}-0.096 ; \mathrm{NiSO}_{4} \times 7 \mathrm{H}_{2} \mathrm{O}-0.048 ; \mathrm{Na}_{2} \mathrm{WO}_{4} \times 2 \mathrm{H}_{2} \mathrm{O}-0.018 ; \mathrm{Ti}_{2}\left(\mathrm{SO}_{4}\right)_{3}-0.040 ;$ 
$\mathrm{Co}\left(\mathrm{NO}_{3}\right)_{2} \times 6 \mathrm{H}_{2} \mathrm{O}-0.044 . \mathrm{Fe}+$ EDTA solution-1 $\mathrm{ml} \cdot \mathrm{l}^{-1}\left(30.2 \mathrm{~g}\right.$ EDTA-Na $\mathrm{Na}_{2}$ was dissolved in $134 \mathrm{ml}$ of $1 \mathrm{M}$ $\mathrm{KOH}$. This solution was diluted with $500 \mathrm{ml}$ of distilled $\mathrm{H}_{2} \mathrm{O}$, and $24.9 \mathrm{~g}$ of $\mathrm{FeSO}_{4} \times 7 \mathrm{H}_{2} \mathrm{O}$ was added, and the volume was adjusted to $1: 1$ with distilled $\mathrm{H}_{2} \mathrm{O}$ (the latter solution requires overnight bubbling with air through $\mathrm{NaOH}$ solution to avoid reaction with $\mathrm{CO}_{2}$ ). Solid Zarrouk medium contained $1 \%$ agar. The culture was grown under continuous illumination $\left(20-50 \mu\right.$ moles photon $\left.\mathrm{m}^{-2} \cdot \mathrm{s}^{-1}\right)$ at $25^{\circ} \mathrm{C}-30^{\circ} \mathrm{C}$. Bacterial contamination was eliminated by the addition of antibiotics, ampicillin $\left(25-50 \mu \mathrm{g} \cdot \mathrm{ml}^{-1}\right)$ or trimethoprim $\left(5-30 \mu \mathrm{g} \cdot \mathrm{ml}^{-1}\right)$. Single colonies that appeared within one to two weeks were plated on fresh medium. Bacterial contamination was tested by growing single clones on a standard LB medium [18] at $30^{\circ} \mathrm{C}-37^{\circ} \mathrm{C}$ for $12-72 \mathrm{~h}$. No fungal or algal contamination was observed.

\subsection{Light and Electron Microscopy}

Morphology of strains was accessed by light microscopy (Axio Imager A1; Carl Zeiss, Germany). Morphological characterization and assignment was done as described previously [19]. Ultrastructure of cyanobacterial cells was analyzed by transmission electron microscopy. Cells from $25 \mathrm{ml}$ of culture were collected by centrifugation at room temperature $(4500 \mathrm{~g}, 5 \mathrm{~min})$ and fixed with $4 \%$ paraformaldehyde in $0.1 \mathrm{M}$ phosphate buffer $(\mathrm{pH} 7.2)$ at $4^{\circ} \mathrm{C}$. Samples were rinsed three times in the same buffer and post-fixed in $1 \% \mathrm{OsO}_{4}$ for $1 \mathrm{~h}$. After dehydration in ethanol and acetone, samples were embedded in Epon resin (Sigma-Aldrich, St. Louis, MO, USA). Cell sections were contrasted with uranyl acetate and then with lead citrate according to Reynolds [20] and analyzed with a Libra-120 transmission electron microscope.

\subsection{Experimental Conditions of Cultivation}

Intensive cultivation was carried out in a custom made installation (apparatus), developed in the laboratory, in glass vessels with $250 \mathrm{ml}$ of Zarrouk medium. Cells were grown under continuous illumination with white luminescent lamps at $110 \mu$ moles of photons $\mathrm{m}^{-2} \cdot \mathrm{s}^{-1}$, and aerated with sterile air-gas mixture that contained $1.5 \%$ $2 \%$ of $\mathrm{CO}_{2}$. To determine the optimal temperature for growth, cultures were incubated at four different temperatures: $24^{\circ} \mathrm{C} \pm 1{ }^{\circ} \mathrm{C}, 27^{\circ} \mathrm{C} \pm 1{ }^{\circ} \mathrm{C}, 32^{\circ} \mathrm{C} \pm 1^{\circ} \mathrm{C}$, and $39^{\circ} \mathrm{C} \pm 1^{\circ} \mathrm{C}$. All growth experiments were repeated, at least, 3 times.

\subsection{DNA Isolation and Cloning of the $16 \mathrm{~S}$ rDNA Fragment}

Total genomic DNA was isolated from cyanobacterial cells by hot phenol [21]. Polymerase chain reaction (PCR) analysis was carried out with GenAmp 2720 thermocycler (Life Technologies, Grand Island, NY, USA). The DNA fragment that corresponded to the 16S rRNA was amplified from the genomic DNA with standard synthetic oligonucleotides used as forward and reverse primers for PCR:

5'-AGAGTTTGATCCTGGCTCAG-3'and5'-AAGGAGGTGATCCAGCC-3' [22]. Another pair of primers (5'-CGGACGGGTGAGTAACGCGTGA and 5-GACTACWGGGGTATCTAATCCCWTT) was used to confirm the presence of the amplified DNA fragments in the recombinant plasmids [23]. Fragments of DNA after purification were cloned in T-vector pTZ57R/T (Fermentas, Vilnius, Lithuania). Competent cells of E. coli strain XL1-Blue (Stratagene, La Jolla, CA, USA) were used for transformation together with the Transform Aid Bacterial Transformation Kit (Fermentas). Isolation of plasmid DNA from cells E. coli was carried out with Gene JET Plasmid Miniprep Kit (Fermentas). Nucleotide sequences of cloned DNA fragments were determined with automated capillary genetic analyzer ABI Prizm 310 (Life Technologies). Alignments of nucleotide sequences [24] were performed with BLAST (http://blast.ncbi.nlm.nih.gov). The determined nucleotide sequence was deposited in GenBank under Accession number KM502966.

\subsection{Lipid Content and Fatty Acid Analysis}

For determination of lipid content and fatty acid composition, samples were withdrawn at the stationary phase of culture that had been grown at $32^{\circ} \mathrm{C}$ and $24^{\circ} \mathrm{C}$. Lipid content and fatty acid composition of the fixed samples of $15-50 \mathrm{ml}$ (depending on the strain and the culturing conditions) were determined as follows. Cells were pelleted by centrifugation at room temperature for $3 \mathrm{~min}$ at $3600 \mathrm{~g}$. The supernatant was removed, and pelleted cells were resuspended in $10 \mathrm{ml}$ of distilled water, quantitatively transferred to $15 \mathrm{ml}$ centrifuge tubes and pelleted again by centrifugation. The supernatant was removed again, and the precipitate was immediately resus- 
pended in $7.5 \mathrm{ml}$ of hot $\left(60^{\circ} \mathrm{C}\right)$ isopropyl alcohol that contained ionol at $0.02 \%$. The tubes were incubated for 10 min in a water bath heated to $65^{\circ} \mathrm{C}$, then capped and stored until analysis at $-20^{\circ} \mathrm{C}$. Fatty acid methyl esters (FAMEs) were prepared by transesterification of the stored materials in a mixture of methanol and acetyl chloride (9:1) for $60 \mathrm{~min}$ at $70^{\circ} \mathrm{C}$. Analysis of the resulting mixture of FAMEs and quantitative content of total lipids in terms of esterified fatty acids was performed with GC-MS Agilent 7890A gas-liquid chromatography system with the mass spectrometric detector Agilent 5975S (Agilent Technology Systems, Santa Clara, CA, USA). The 60 -m capillary column DB-23 ( $\varnothing 0.25 \mathrm{~mm}$; Fischer Scientific, Loughborough, UK) was filled with $50 \%$ cyanopropyl methylpolysiloxane. Other separation conditions for FAMEs were as follows: helium pressure in the injector was $245 \mathrm{kPa}$; flow rate of $1 \mathrm{ml} \cdot \mathrm{min}^{-1}$; volume of the sample solution was $1 \mu \mathrm{l}$; flow divider 1:5; and the evaporation temperature of $260^{\circ} \mathrm{C}$. Program of column gradient temperature: jump from $130^{\circ} \mathrm{C}$ to $170^{\circ} \mathrm{C}$ at $6.5^{\circ} \mathrm{C}$ per min; jump from $170^{\circ} \mathrm{C}$ to $215^{\circ} \mathrm{C}$ at $2.75^{\circ} \mathrm{C}$ per min; holding at $215^{\circ} \mathrm{C}$ for $25 \mathrm{~min}$, jump from $215^{\circ} \mathrm{C}$ to $240^{\circ} \mathrm{C}$ at $40^{\circ} \mathrm{C}$ per min; and holding at $240^{\circ} \mathrm{C}$ for $50 \mathrm{~min}$. Operating temperature of MS detector was $240^{\circ} \mathrm{C}$, at the ionization energy of $70 \mathrm{eV}$. Heptadecanoic acid (17:0) was used as the internal standard.

\section{Results}

\subsection{Isolation and Purification of the Cyanobacterial Strain}

Water samples from Lake Balkhash were plated on BG11 [25] or Zarrouk [17] media. Single colonies were picked up from Zarrouk medium, diluted and sprayed again on fresh agar-containing plates. No fungal or algal contaminations were observed in the initial culture. To eliminate bacterial contamination, ampicillin or trimethoprim were used. While ampicillin did not prove effective, trimethoprim, a bacteriostatic antibiotic, at 5 - 30 $\mu \mathrm{g} \cdot \mathrm{ml}^{-1}$ was efficient to clean the cyanobacterial culture from contamination of other bacteria. Trimethoprim usually does not affect growth of cyanobacteria, such as Synechocystis sp. PCC 6803 or Synechococcus elongatus PCC 7942 ([26]; our unpublished observations), while inhibits E. coli and many other Gram-negative and Gram-positive bacterial species. Thus, we isolated the axenic cyanobacterial strain, which was deposited to the Collection of Microalgae and Cyanobacteria of the Institute of Plant Physiology RAS (Moscow, Russia) under accession number IPPAS B-1200.

\subsection{Morphological and Structural Characterization of the Isolated Cyanobacterial Strain}

Isolated colonies were blue-green, lustrous, circular, smooth, with straight edges (Figure 1). Light (Figure 1) and electron (Figure 2) microscopy of samples revealed the presence of cells of cyanobacteria resembling Cyanobacterium spp. of Chroococcales [27]. Cells were non-motile, solitary or in pairs after division, without

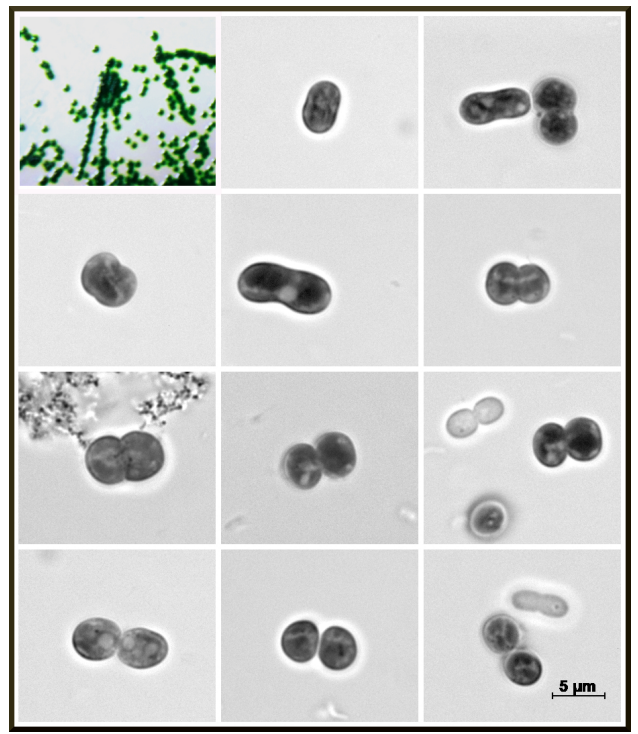

Figure 1. Colonies on agar and cells and of the isolated strain under light microscope. 

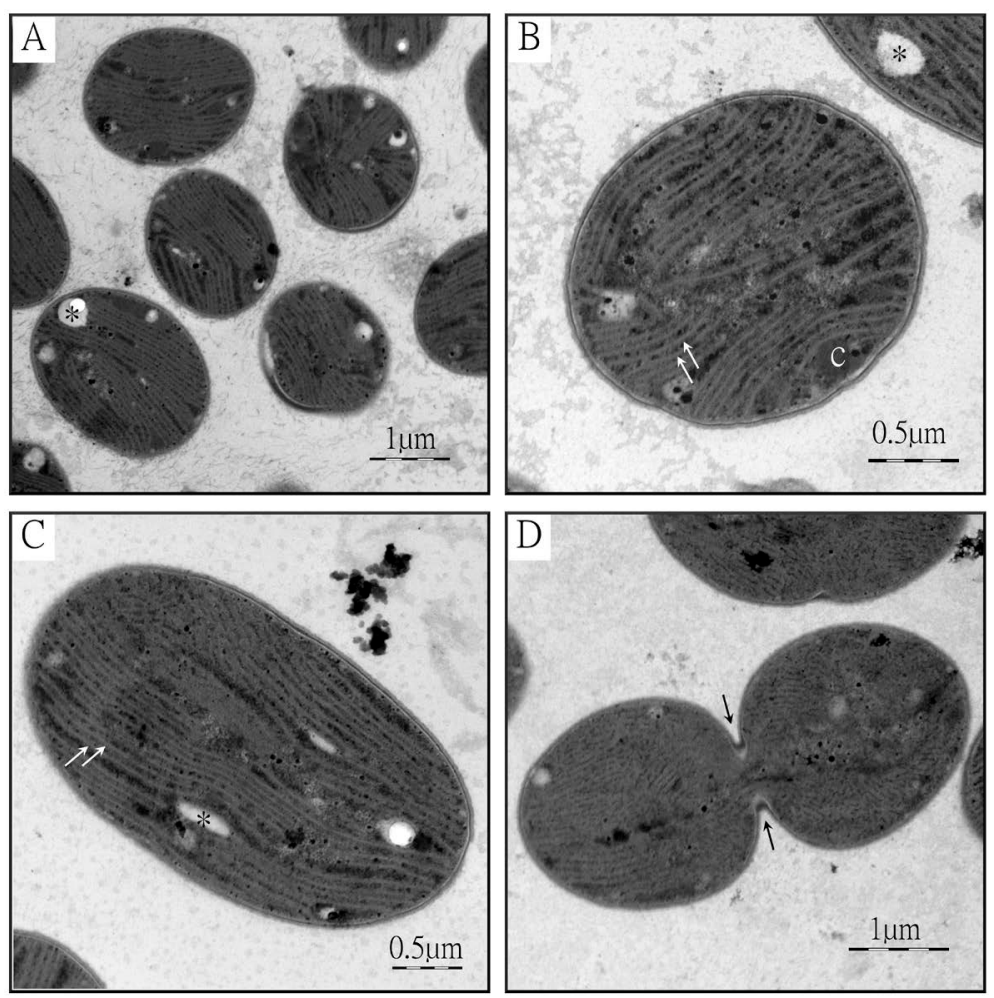

Figure 2. Electron microphotographs of cells of the isolated cyanobacterial strain: (A) - general view of cell population at low magnification; (B) - cross section of a cell with radial thylakoids; (C) - longitudinal section with lengthwise oriented thylakoids; (D) — dividing cells; c-carboxysomes; asterisks indicate inclusions with low electron density; white arrows mark thylakoid membranes; black arrows indicate invagination of cell wall in a dividing cell.

gelatinous envelopes, oval to rod-shaped with rounded ends, with average $4.5-7.5 \mu \mathrm{m}$ length, $2.0-4.5 \mu \mathrm{m}$ width, straight or slightly arcuate. Cell content had no separation on centro- and chromatoplasma. Cell division occurred by binary fission in transverse plane to longer cell axes and resulted in two isomorphic daughter cells (Figure 1 and Figure 2(D)).

Ultrastructural analysis revealed radial thylakoids on cross-sections and lengthwise oriented thylakoids on longitudinal sections (Figures 2(A)-(C)). Few inclusion bodies were seen on sections: carboxysomes (Figure 2(B)) and inclusions with low electron density (Figures 2(A)-(C)). No S-layer or sheaths were observed on the outer membrane of cells.

Morphological and ultrastructural features of the isolated strain mostly fitted to the description of Cyanobacterium stanieri [27], which is considered to be a type strain of the genus Cyanobacterium [28]-[30]. The newly isolated strain differed from Cyanobacterium stanieri by bigger cell size (cells of the type strain are typically of $3.7-5.2 \times 2-3.4 \mu \mathrm{m})$ and by the ability to excrete significant amount of mucilage, which was not attached to cells.

\subsection{Growth Characteristics}

A similar doubling time ( 9 - $11 \mathrm{~h}$ in the exponential phase) was observed during cultivation of the strain at $24^{\circ} \mathrm{C}$, $27^{\circ} \mathrm{C}$ or $32^{\circ} \mathrm{C}$ (Figure 3). At lower temperatures $\left(24^{\circ} \mathrm{C}-27^{\circ} \mathrm{C}\right.$ ), cultures had longer lag-phase, after which it could grow at a similar rate as at $32^{\circ} \mathrm{C}$. At high temperatures $\left(39^{\circ} \mathrm{C}\right)$, retardation of growth after the first day of incubation was observed (Figure 3). The ability of this strain to grow intensively in a rather wide temperature range is preferable for biotechnological applications, since it allows a deviation of daily cultivation temperature considerably. The absorption spectrum of cell suspension of the isolated strain was typical to unicellular cyanobacteria that contain chlorophyll $a$ (not shown). 


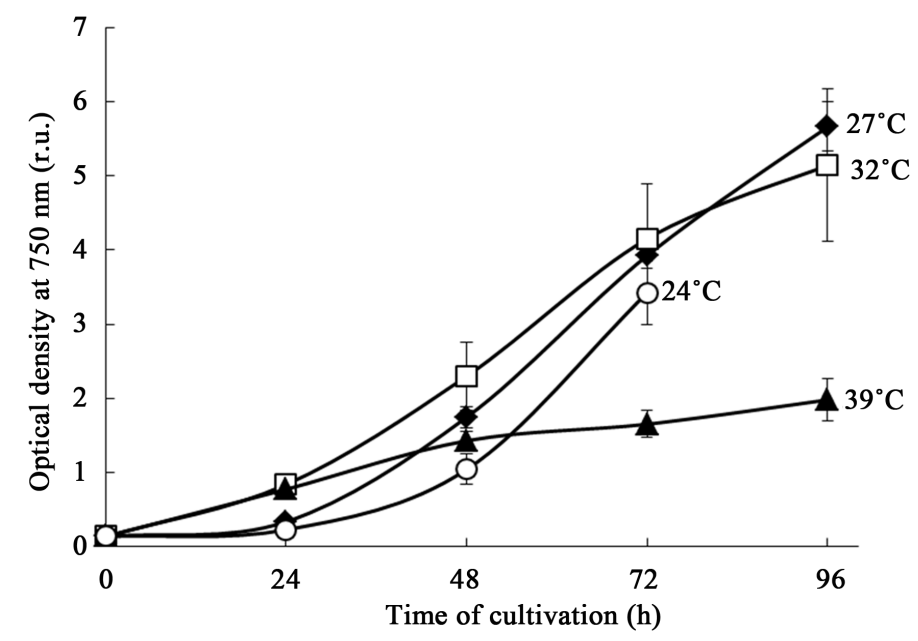

Figure 3. Growth curves of the isolated strain at different temperatures. Bars show standard deviations from 3 independent experiments. r.u.reference units.

\subsection{S DNA Cloning and Phylogenetic Analysis}

The DNA fragment of 1488 bp that corresponded to the full-length 16S rRNA was amplified by PCR from the genomic DNA with a standard set of primers [22] as described in Materials and Methods. Amplified DNA fragments have been cloned into a T-type vector, and their nucleotide sequences were determined (GenBank Accession No. KM502966) (Figure 4).

The nucleotide sequence of DNA fragment that corresponded to the 16S small ribosomal RNA of the isolated cyanobacterium displayed the highest degree of homology to the 16S ribosomal RNA gene of Cyanobacterium stanieri strain PCC 7202 [31] (Table 1) or to some uncultured bacteria. The latter are, probably, the representatives of cyanobacterial species from environmental water samples that have been subjected to metagenomic analysis [32]. Thus, on the basis of microscopic and molecular studies, we assigned the newly isolated strain as Cyanobacterium sp. IPPAS B-1200.

\subsection{Fatty Acid Composition of Cyanobacterium sp. IPPAS B-1200}

Cells of Cyanobacterium sp. IPPAS B- 1200 were grown at $32^{\circ} \mathrm{C}$ or $24^{\circ} \mathrm{C}$ until they reached the stationary growth phase. The isolated and transesterified FAMEs were resolved by GC-MS. Typical GC profile is represented in Figure 5. The cells of Cyanobacterium sp. IPPAS B-1200 accumulated up to $60 \mathrm{mg}$ of FAs per gram of dry weight. The effect of temperature on FA composition was not observed. The cells were characterized by rather simple FA composition (Table 2) and contained equal amounts of saturated and monounsaturated (about $50 \%$ each) FAs. Palmitic (16:0) and palmitoleic (16:1 $\Delta 9)$ acids make $40 \%$ and $10 \%$, respectively. $\mathrm{C}_{18}$ fatty acids are present in negligibly low amounts. The unique feature of Cyanobacterium sp. IPPAS B-1200 is that myristic $(14: 0)$ and myristoleic $(14: 1 \Delta 9)$ acids are present in cells at high amounts $-30 \%$ and $10 \%$, respectively.

According to the proposed classification [9], the presence of only monounsaturated FAs assigns this strain to cyanobacteria of Group 1, which includes mesophilic and thermophilic species of unicellular cyanobacteria [9] [33]-[36].

\section{Discussion}

Fatty acid composition of lipids of cyanobacteria is conserved and it can be used as the phylogenetic marker [33] [35]. All cyanobacterial strains have been previously tagged into four distinct groups according to their FA composition [9].

The organisms of Group 1 synthesize only monoenoic fatty acids usually desaturated at $\Delta 9$ position. Recent advances in genomic sequencing and biochemical analysis reveal that such desaturation may be performed by different isozymes of the $\Delta 9$-desaturase. Some of these isozymes are specific to $s n-1$ or $s n-2$ positions of the 


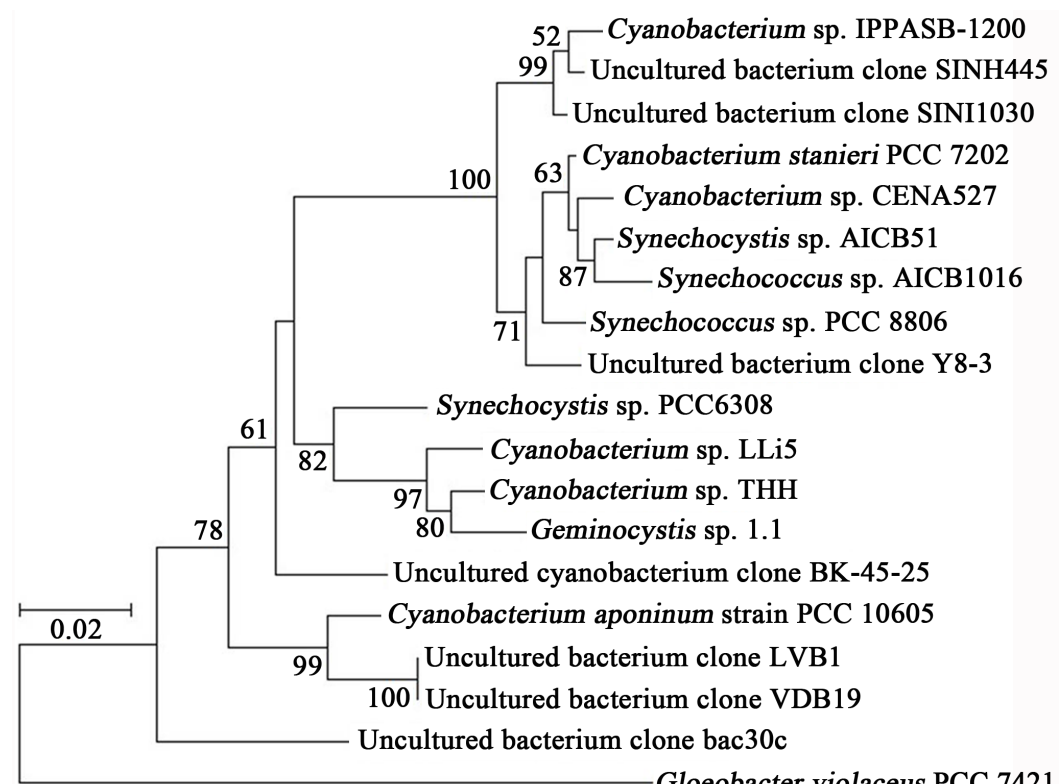

Figure 4. Maximum-likelihood phylogenetic tree based on 16S rRNA gene sequences that produced highest homology score with GenBank sequence KM502966 (Cyanobacterium sp. IPPAS B-1200) and with Gloeobacter violaceus PCC 7421 (NR_074282) as an out-group. Bootstrap values $>50 \%$ are shown above branches. GenBank accession numbers are shown in Table 1.

Table 1. Nucleotide sequences that produced high alignment score.

\begin{tabular}{|c|c|c|c|c|c|}
\hline Accession & Description & $\begin{array}{c}\text { Max } \\
\text { Score }\end{array}$ & $\begin{array}{l}\text { Total } \\
\text { Score }\end{array}$ & $\begin{array}{l}\text { Query } \\
\text { Cover }\end{array}$ & Identity \\
\hline CP003940.1 & Cyanobacterium stanieri PCC 7202, complete genome & 2532 & 7319 & $99 \%$ & $98 \%$ \\
\hline HM128012.1 & Uncultured bacterium clone SINH445 16S rRNA gene, partial & 2516 & 2516 & $95 \%$ & $99 \%$ \\
\hline HM126696.1 & Uncultured bacterium clone SINI1030 16S rRNA gene, partial & 2508 & 2508 & $95 \%$ & $99 \%$ \\
\hline KF912998.1 & Uncultured bacterium clone Y8-3 16S rRNA gene, partial & 2431 & 2431 & $97 \%$ & $97 \%$ \\
\hline KF246493.1 & Cyanobacterium sp. CENA527 16S rRNA gene, partial & 2405 & 2405 & $95 \%$ & $97 \%$ \\
\hline AF448077.1 & Synechococcus sp. PCC 8806 16S rRNA gene, partial & 2398 & 2398 & $95 \%$ & $97 \%$ \\
\hline KJ746512.1 & Synechocystis sp. AICB51 16S rRNA gene partial & 2385 & 2385 & $95 \%$ & $97 \%$ \\
\hline KJ746511.1 & Synechococcus sp. AICB1016 16S rRNA gene partial & 2340 & 2340 & $96 \%$ & $96 \%$ \\
\hline FJ866623.1 & Uncultured cyanobacterium clone BK-45-25 16S rRNA gene, partial & 2148 & 2148 & $98 \%$ & $93 \%$ \\
\hline СР003947.1 & Cyanobacterium aponinum PCC 10605, complete genome & 2146 & 6403 & $99 \%$ & $93 \%$ \\
\hline DQ786164.1 & Cyanobacterium sp. LLi5 16S rRNA gene, partial & 2143 & 2143 & $98 \%$ & $93 \%$ \\
\hline KC621874.1 & Cyanobacterium sp. THH $16 \mathrm{~S}$ rRNA gene, partial & 2137 & 2137 & $97 \%$ & $93 \%$ \\
\hline JX504279.1 & Uncultured bacterium clone bac30c $16 \mathrm{~S}$ rRNA gene, partial & 2108 & 2108 & $99 \%$ & $92 \%$ \\
\hline KJ465919.1 & Uncultured bacterium clone LVB1 $16 \mathrm{~S}$ rRNA gene, partial & 2106 & 2106 & $97 \%$ & $93 \%$ \\
\hline KJ465958.1 & Uncultured bacterium clone VDB19 16S rRNA gene, partial & 2102 & 2102 & $97 \%$ & $93 \%$ \\
\hline AB039001.1 & Synechocystis PCC 6308 gene for $16 \mathrm{~S}$ rRNA, partial & 2102 & 2102 & $97 \%$ & $93 \%$ \\
\hline
\end{tabular}




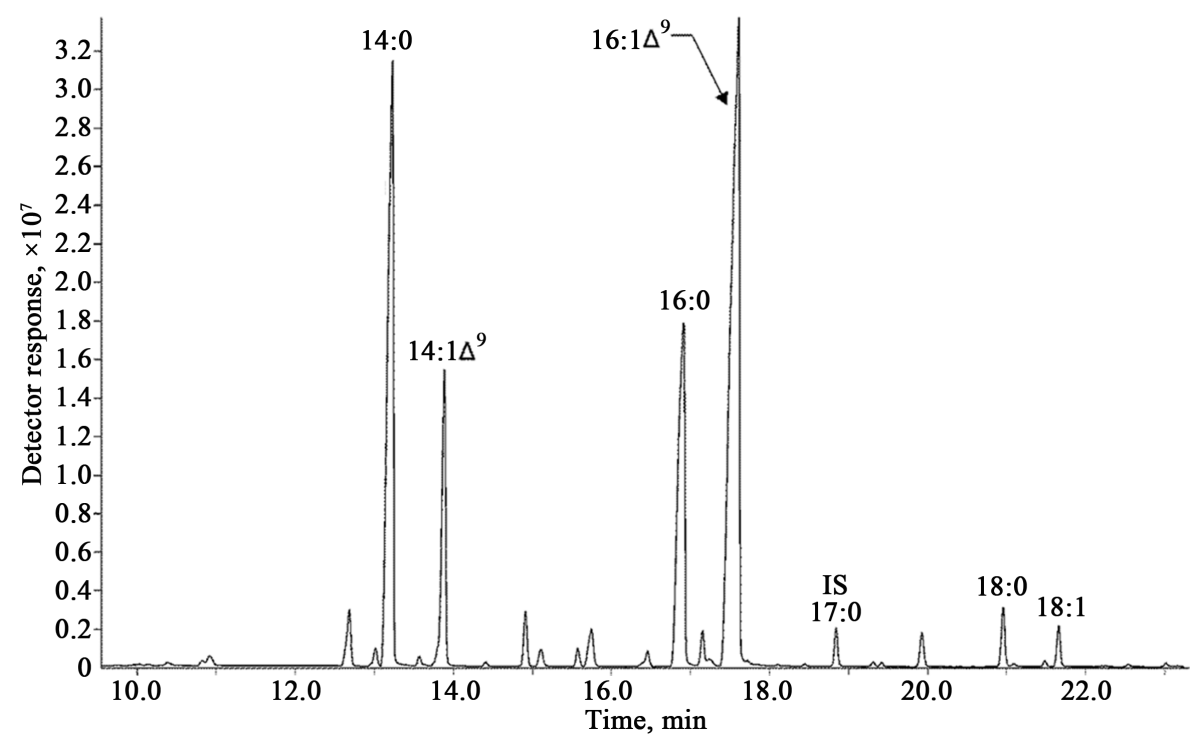

Figure 5. Typical profile of FAs separation by gas chromatography; IS - internal standard (17:0). Samples were prepared by direct transesterification.

Table 2. Fatty acid composition of Cyanobacterium sp. IPPAS B-1200.

\begin{tabular}{ccc}
\hline \multirow{2}{*}{ Fatty Acids } & \multicolumn{3}{c}{ Content of Fatty Acids, mol \% $^{\text {a }}$} \\
\cline { 2 - 3 } & $\mathbf{3 2}^{\circ} \mathbf{C}$ & $\mathbf{2 4}^{\circ} \mathbf{C}$ \\
\hline $14: 0$ & 29 & 30 \\
$14: 1 \Delta 9$ & 9 & 10 \\
$16: 0$ & 20 & 17 \\
$16: 1 \Delta 9$ & 39 & 40 \\
$18: 0$ & 1 & 1 \\
$18: 1^{*}$ & 2 & 2 \\
\hline
\end{tabular}

${ }^{\mathrm{a}}$ The deviation of values was within $0.1 \%-1 \%$; ${ }^{*}$ Sum of $18: 1 \Delta 9$ and $18: 1 \Delta 11$.

glycerol moiety [35]. The presence of five genes for the $\Delta 9$-desaturases in the genome of Gloeobacter violaceus [37] suggests that some isozymes may be also specific to the carbon chain length of FAs. On the other hand, the presence of only one gene for the $\Delta 9$-desaturase in the genomes of Synechococcus elongatus PCC 7942 (NCBI Reference Sequence NC_007604) or 6301 (NC_006576) and the appearance of 18:1 and 16:1 at sn-1 and sn-2 positions [9] suggest that some of $\Delta 9$-desaturases may be not as specific as others.

The cyanobacterial strains of Group 2 have three distinct FA desaturases and can synthesize trienoic $\alpha$-linolenic acid, 18:3 $\Delta 9,12,15$.

Organisms of Group 3 also have three distinct desaturases, but, instead of $\Delta 15$, they introduce a double bond at position $\Delta 6$ and produce trienoic $\gamma$-linolenic acid, 18:3 $\Delta 6,9,12$, as a final product of desaturation.

Strains of Group 4 have four desaturases and synthesize tetraenoic stearidonic acid, 18:4 $\Delta 6,9,12,15$.

Nowadays, a new group of marine cyanobacteria has emerged that has two FA desaturases, $\Delta 9$ - and $\Delta 12$-desaturases

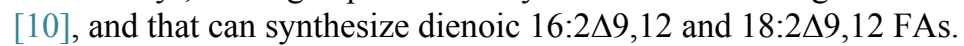

The identified strain, Cyanobacterium sp. IPPAS B-1200, belongs to Group 1, and it can produce only saturated and monounsaturated fatty acids (Table 2). To our knowledge, this is the first characterized cyanobacterial strain that possesses very high amounts of $\mathrm{C}_{14}$ FAs: 14:0 (30\%) and 14:1 $\Delta 9(10 \%)$.

The chlorophyll $b$ containing representative of Prochlorales, Prochlorothrix hollandica, which is known as a $\mathrm{C}_{14}$-rich organism, possesses $5 \%$ of $14: 0$ and $30 \%$ of $14: 1 \Delta 9$ [15]. Prochlorothrix, also with $\Delta 9$-desaturase, has the unique $\Delta 4$-desaturase activity and produces unusual $16: 1 \Delta 4(25 \%)$ and $16: 2 \Delta 4,9(10 \%)$ FAs [15]. The ge- 
netic data for the cyanobacterial $\Delta 4$-desaturase is still unavailable. Nevertheless, the presence of high amounts of 16:2 $\Delta 4,9$ (and the complete absence of 18:2 FAs) should place Prochlorothrix hollandica to an additional specialized Group of cyanobacteria classified according to their FA composition.

Phylogenetic analysis based on 16S rRNA sequence reveals that the closest relative to the newly identified strain Cyanobacterium sp. IPPAS B-1200 is Cyanobacterium stanieri PCC 7202 [38]. Among two putative genes annotated as fatty acid desaturases in the genome of the Cyanobacterium stanieri PCC 7202 (Accession number CP003940 [31]), one gene, AFZ46762 (Cyast_0790), encodes the $\beta$-carotene hydroxylase, but not fatty acid desaturase. The other gene, YP_007164144 (Cyast_0516), encodes the real $\Delta 9$-acyl-lipid desaturase. Therefore, FAs of Cyanobacterium stanieri PCC 7202 should be represented only by saturated and monounsaturated components, and Cyanobacterium stanieri PCC 7202 should belong to cyanobacteria of Group 1. However, experimental data on FA composition of that strain are missing.

Cyanobacterium stanieri PCC 7202 was originally classified as Synechococcus sp. PCC 7202. Later, it was separated from Synechococcus into a new genus due to morphological, biochemical and genetic differences [28] [39]. The original reference strains of fresh-water Synechococcus, Anacystis nidulans PCC 6301 and Synechococcus sp. PCC 7942, have been renamed to Synechococcus elongatus PCC 6301 and Synechococcus elongatus PCC 7942, respectively. These two genetically and closely related strains belong to Group 1 . They possess one $\Delta 9$-desaturase gene, and they are able to synthesize only monounsaturated FAs. In this aspect, the affiliation of some marine species, which belong to Group 3 (Synechococcus sp. PCC 7002 that synthesizes trienoic FAs) or to a newly selected group (organisms that synthesize dienoic FAs), with the genus Synechococcus, looks somewhat questionable.

Morphology and ultrastructure of Cyanobacterium sp. IPPAS B-1200 are closer to Cyanobacterium stanieri than to Synechococcus elongatus (Figure 1 and Figure 2). In the NCBI taxonomy database, Cyanobacterium stanieri PCC 7202 (Taxonomy ID: 292563) is placed together with its synonyms: Synechococcus sp. PCC 7202 and Synechococcus cedrorum CCAP 14792. Synechococcus cedrorum (no genomic data are available) is characterized by the presence of only monounsaturated FAs (16:0 47\%, 16:1 39\%, and 18:1 10\%) [33] [34]. The shape and morphological features of Synechococcus cedrorum resemble that of Synechococcus elongatus [34], but not Cyanobacterium stanieri PCC 7202 [28]. The origin and systematic position of Synechococcus cedrorum were already questioned in the previous century [28]; however, it seems that the problem still remains unsolved.

Thus, we have isolated, from Lake Balkhash, Republic of Kazakhstan, purified and identified a new representative of unicellular cyanobacteria, which was named Cyanobacterium sp. IPPAS B-1200, according to its morphological characteristics, 16S rRNA analysis and FA composition. Lipids of this strain are rich in $\mathrm{C}_{14}$ myristic and myristoleic acids (30\% and $10 \%$, respectively) and in $\mathrm{C}_{16}$ palmitic and palmitoleic acids $(20 \%$ and $40 \%$, respectively). This simple and unusual FA composition makes this strain a good candidate for synthesis of the carbon chains suitable for biodiesel production.

\section{Acknowledgements}

This work was supported by grants from Russian Scientific Foundation Nos. 14-14-00904 to M.A.S. and 14-2400020 to D.A.L. and by a grant from Ministry of Education and Science of Republic of Kazakhstan to B.K.Z.

\section{References}

[1] Schopf, J.W. (1993) Microfossils of the Early Archean Apex Chert: New Evidence of the Antiquity of Life. Science, 260, 640-646. http://dx.doi.org/10.1126/science.260.5108.640

[2] Kufryk, G. (2013) Advances in Utilizing Cyanobacteria for Hydrogen Production. Advances in Microbiology, 3, 60-68. http://dx.doi.org/10.4236/aim.2013.36A008

[3] Gao, Z., Zhao, H., Li, Z., Tan, X. and Lu, X. (2012) Photosynthetic Production of Ethanol from Carbon Dioxide in Genetically Engineered Cyanobacteria. Energy \& Environmental Science, 5, 9857-9865. http://dx.doi.org/10.1039/c2ee22675h

[4] Deng, M.-D. and Coleman, J.R. (1999) Ethanol Synthesis by Genetic Engineering in Cyanobacteria. Applied \& Environmental Microbiology, 65, 2523-528. http://aem.asm.org/content/65/2/523.full

[5] Varman, A.M., Xiao, Y., Pakrasi, H.B. and Tang, Y.J. (2013) Metabolic Engineering of Synechocystis sp. Strain PCC 6803 for Isobutanol Production. Applied Environmental Microbiology, 79, 3908-3914. 
http://dx.doi.org/10.1128/AEM.02827-12

[6] Nicole, E., Nozzi, N.E., Oliver, J.W.K. and Atsumi, S. (2013) Cyanobacteria as a Platform for Biofuel Production. Frontiers in Bioengineering and Biotechnology, 1, 7. http://dx.doi.org/10.3389/fbioe.2013.00007

[7] Robertson, D.E., Jacobson, S.A., Morgan, F., Berry, D., Church, G.M. and Afeyan, N.B. (2011) A New Dawn for Industrial Photosynthesis. Photosynthesis Research, 107, 269-277. http://dx.doi.org/10.1007/s11120-011-9631-7

[8] Tan, X., Yao, L., Gao, Q., Wang, W., Qi, F. and Lu, X. (2011) Photosynthesis Driven Conversion of Carbon Dioxide to Fatty Alcohols and Hydrocarbons in Cyanobacteria. Metabolic Engineering, 13, 169-176. http://dx.doi.org/10.1016/j.ymben.2011.01.001

[9] Murata, N., Wada, H. and Gombos, Z. (1992) Modes of Fatty-Acid Desaturation in Cyanobacteria. Plant \& Cell Physiology, 33, 933-941. http://pcp.oxfordjournals.org/content/33/7/933.full.pdf + html

[10] Chi, X., Yang, Q., Zhao, F., Qin, S., Yang, Y., Shen, J. and Lin, H. (2008) Comparative Analysis of Fatty Acid Desaturases in Cyanobacterial Genomes. Comparative and Functional Genomics, 2008, Article ID: 284508, 25 p. http://dx.doi.org/10.1155/2008/284508

[11] Lu, X. (2010) A Perspective: Photosynthetic Production of Fatty Acid-Based Biofuels in Genetically Engineered Cyanobacteria. Biotechnology Advances, 28, 742-746. http://dx.doi.org/10.1016/j.biotechadv.2010.05.021

[12] Parker, P.L., van Baalen, C. and Maurer, L. (1967) Fatty Acids in Eleven Species of Blue-Green Algae: Geochemical Significance. Science, 155, 707-708. http://dx.doi.org/10.1126/science.155.3763.707

[13] Shemet, V., Karduck, P., Hoven, H., Grushko, B., Fischer, W., Quadakkers, W.J., Carpenter, E.J., Harvey, H.R., Fry, B. and Capone, D.G. (1997) Biogeochemical Tracers of the Marine Cyanobacterium Trichodesmium. Deep Sea Research Part I: Oceanographic Research Papers, 44, 27-38. http://dx.doi.org/10.1016/S0967-0637(96)00091-X

[14] Oren, A., Fattom, A., Padan, E. and Tietz, A. (1985) Unsaturated Fatty Acid Composition and Biosynthesis in Oscillatoria limnetica and Other Cyanobacteria. Archives of Microbiology, 141, 138-142. http://dx.doi.org/10.1007/BF00423274

[15] Gombos, Z. and Murata, N. (1991) Lipids and Fatty Acids of Prochlorothrix hollandica. Plant \& Cell Physiology, 32, 73-77. http://pcp.oxfordjournals.org/content/32/1/73.full.pdf + html

[16] Zarrouk, C. (1966) Contribution à l'étuded'unecyanophycée. Influence de Divers Facteurs Physiques et Chimiques Sur la Croissance et la Photosynthèse de Spirulina maxima. Ph.D. Thesis, Université De Paris, Paris.

[17] Vonshak, A., Abeliovich, A., Boussiba, S., Arad, S. and Richmond, A. (1982) On the Production of Spirulina Biomass: Effects of Environmental Factors and of the Population Density. Biomass, 2, 175-185. http://dx.doi.org/10.1016/0144-4565(82)90028-2

[18] Bertani, G. (1952) Studies on Lysogenesis. I. The Mode of Phage Liberation by Lysogenic Escherichia coli. Journal of Bacteriology, 62, 293-300. http://jb.asm.org/content/62/3/293.full.pdf + html

[19] Komárek, J. (2006) Cyanobacterial Taxonomy: Current Problems and Prospects for the Integration of Traditional and Molecular Approaches. Algae, 21, 249-375. http://dx.doi.org/10.4490/algae.2006.21.4.349

[20] Reynolds, E.S. (1963) The Use of Lead Citrate at High pH as an Electronopaque Stain in Electron Microscopy. Journal of Cell Biology, 17, 208-212. http://www.ncbi.nlm.nih.gov/pmc/articles/PMC2106263/pdf/208.pdf

[21] Kiseleva, L.L., Serebriiskaya, T.S., Horvath, I., Vigh, L., Lyukevich, A.A. and Los, D.A. (2000) Expression of the Gene for the $\Delta 9$ Acyl-Lipid Desaturase in the Thermophilic Cyanobacterium. Journal of Molecular Microbiology and Biotechnology, 2, 331-338.

[22] Weisburg, W.G., Barns, S.M., Pelletier, D.A. and Lane, D.J. (1991) 16S Ribosomal DNA Amplification for Phylogenetic Study. Journal of Bacteriology, 173, 697-703. http://jb.asm.org/content/173/2/697

[23] Nübel, U., Garcia-Pichel, F. and Muyzer, G. (1997) PCR Primers to Amplify 16S rRNA Genes from Cyanobacteria. Applied and Environmental Microbiology, 63, 3327-3332. http://aem.asm.org/content/63/8/3327

[24] Zhang, Z., Schwartz, S., Wagner, L. and Miller, W. (2000) A Greedy Algorithm for Aligning DNA Sequences. Journal of Computational Biology, 7, 203-214. http://dx.doi.org/10.1089/10665270050081478

[25] Rippka, R. (1988) Isolation and Purification of Cyanobacteria. Methods in Enzymology, 167, 3-27. http://dx.doi.org/10.1016/0076-6879(88)67004-2

[26] van der Grinten, E., Pikkemaat, M.G., van den Brandhof, E.J., Stroomberg, G.J. and Kraak, M.H. (2010) Comparing the Sensitivity of Algal, Cyanobacterial and Bacterial Bioassays to Different Groups of Antibiotics. Chemosphere, $\mathbf{8 0}$, 1-6. http://dx.doi.org/10.1016/j.chemosphere.2010.04.011

[27] Komárek, J. and Anagnostidis, K. (1999) Cyanoprokaryota. I. Chroococcales. In: Ettl, H., Gärtner, G., Heynig, H. and Mollenhauer, D., Eds., Süßwasserflora von Mitteleuropa, Begründet von A. PascherBd. 19/3 Cyanoprokaryota. 1. Teil Chroococcales, Spektrum, Akademischer Verlag, Heidelberg \& Berlin, 1-548. 
[28] Komárek, J., Kopecký, J. and Cepák, V. (1999) Generic Characters of the Simplest Cyanoprokaryotes, Cyanobium, Cyanobacterium and Synechococcus. Cryptogamie Algologie, 20, 209-222. http://dx.doi.org/10.1016/S0181-1568(99)80015-4

[29] Tamura, K. and Nei, M. (1993) Estimation of the Number of Nucleotide Substitutions in the Control Region of Mitochondrial DNA in Humans and Chimpanzees. Molecular Biology and Evolution, 10, 512-526. http://mbe.oxfordjournals.org/content/10/3/512.long

[30] Tamura, K., Stecher, G., Peterson, D., Filipski, A. and Kumar, S. (2013) MEGA6: Molecular Evolutionary Genetics Analysis Version 6.0. Molecular Biology and Evolution, 30, 2725-2729. http://dx.doi.org/10.1093/molbev/mst197

[31] Shih, P.M., Wu, D., Latifi, A., Axen, S.D., Fewer, D.P., Talla, E., Calteau, A., Cai, F., Tandeau de Marsac, N., Rippka, R., Herdman, M., Sivonen, K., Coursin, T., Laurent, T., Goodwin, L., Nolan, M., Davenport, K.W., Han, C.S., Rubin, E.M., Eisen, J.A., Woyke, T., Gugger, M. and Kerfeld, C.A. (2013) Improving the Coverage of the Cyanobacterial Phylum Using Diversity-Driven Genome Sequencing. Proceedings of the National Academy of Sciences of the United States of America, 110, 1053-1058. http://dx.doi.org/10.1073/pnas.1217107110

[32] Simon, C. and Daniel, R. (2011) Metagenomic Analyses: Past and Future Trends. Applied and Environmental Microbiology, 77, 1153-1161. http://dx.doi.org/10.1128/AEM.02345-10

[33] Holton, R.W., Blecker, H.H. and Stevens, T.S. (1968) Fatty Acids in Blue-Green Algae: Possible Relation to Phylogenetic Position. Science, 160, 545-547. http://dx.doi.org/10.1126/science.160.3827.545

[34] Sherman, L.A. (1978) Differences in Photosynthesis-Associated Properties of Blue-Green Algae Synechococcus cedrorum Grown at $30^{\circ} \mathrm{C}$ and 40 . Journal of Phycology, 14, 427-433. http://dx.doi.org/10.1111/j.1529-8817.1978.tb02462.x

[35] Kenyon, C.N. and Stanier, R.Y. (1970) Possible Evolutionary Significance of Polyunsaturated Fatty Acids in BlueGreen Algae. Nature, 227, 1164-1166. http://dx.doi.org/10.1038/2271164a0

[36] Chintalapati, S., Prakash, J.S., Gupta, P., Ohtani, S., Suzuki, I., Sakamoto, T., Murata, N. and Shivaji, S. (2006) A Novel $\Delta^{9}$ Acyl-Lipid Desaturase, DesC2, from Cyanobacteria Acts on Fatty Acids Esterified to the sn-2 Position of Glycerolipids. Biochemical Journal, 398, 207-214. http://dx.doi.org/10.1042/BJ20060039

[37] Nakamura, Y, Kaneko, T., Sato, S., Mimuro, M., Miyashita, H., Tsuchiya, T., Sasamoto, S., Watanabe, A., Kawashima, K., Kishida, Y., Kiyokawa, C., Kohara, M., Matsumoto, M., Matsuno, A., Nakazaki, N., Shimpo, S., Takeuchi, C., Yamada, M. and Tabata, S. (2003) Complete Genome Structure of Gloeobacter violaceus PCC 7421, a Cyanobacterium That Lacks Thylakoids (Supplement). DNA Research, 10, 181-201. http://dx.doi.oeg/10.1093/dnares/10.4.181

[38] Turner, S., Pryer, K.M., Miao, V.P. and Palmer, J.D. (1999) Investigating Deep Phylogenetic Relationships among Cyanobacteria and Plastids by Small Subunit rRNA Sequence Analysis. Journal of Eukaryotic Microbiology, 46, 327338. http://dx.doi.org/10.1111/j.1550-7408.1999.tb04612.x

[39] Rippka, R. and Cohen-Bazire, G. (1983) The Cyanobacteriales: A Legitimate Order Based on the Type Strain Cyanobacterium stanieri? Annales de l'Institut Pasteur/Microbiologie, 134, 21-36. http://dx.doi.org/10.1016/S0769-2609(83)80094-5 
Scientific Research Publishing (SCIRP) is one of the largest Open Access journal publishers. It is currently publishing more than 200 open access, online, peer-reviewed journals covering a wide range of academic disciplines. SCIRP serves the worldwide academic communities and contributes to the progress and application of science with its publication.

Other selected journals from SCIRP are listed as below. Submit your manuscript to us via either submit@scirp.org or Online Submission Portal.
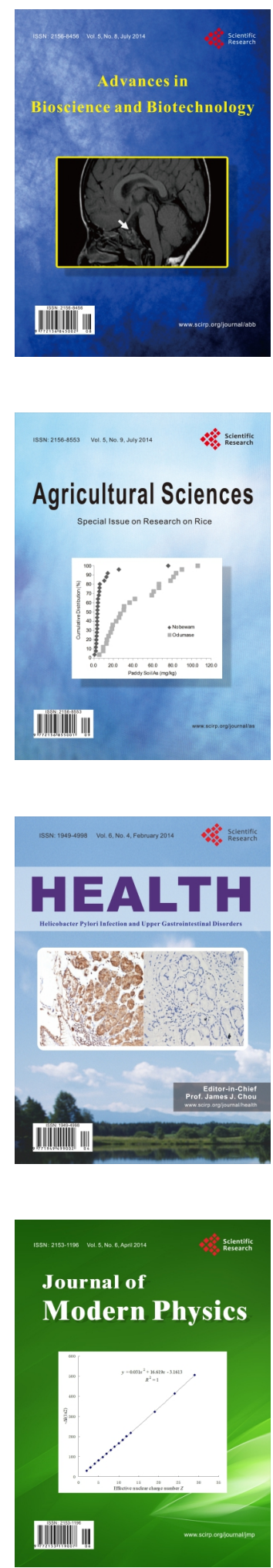
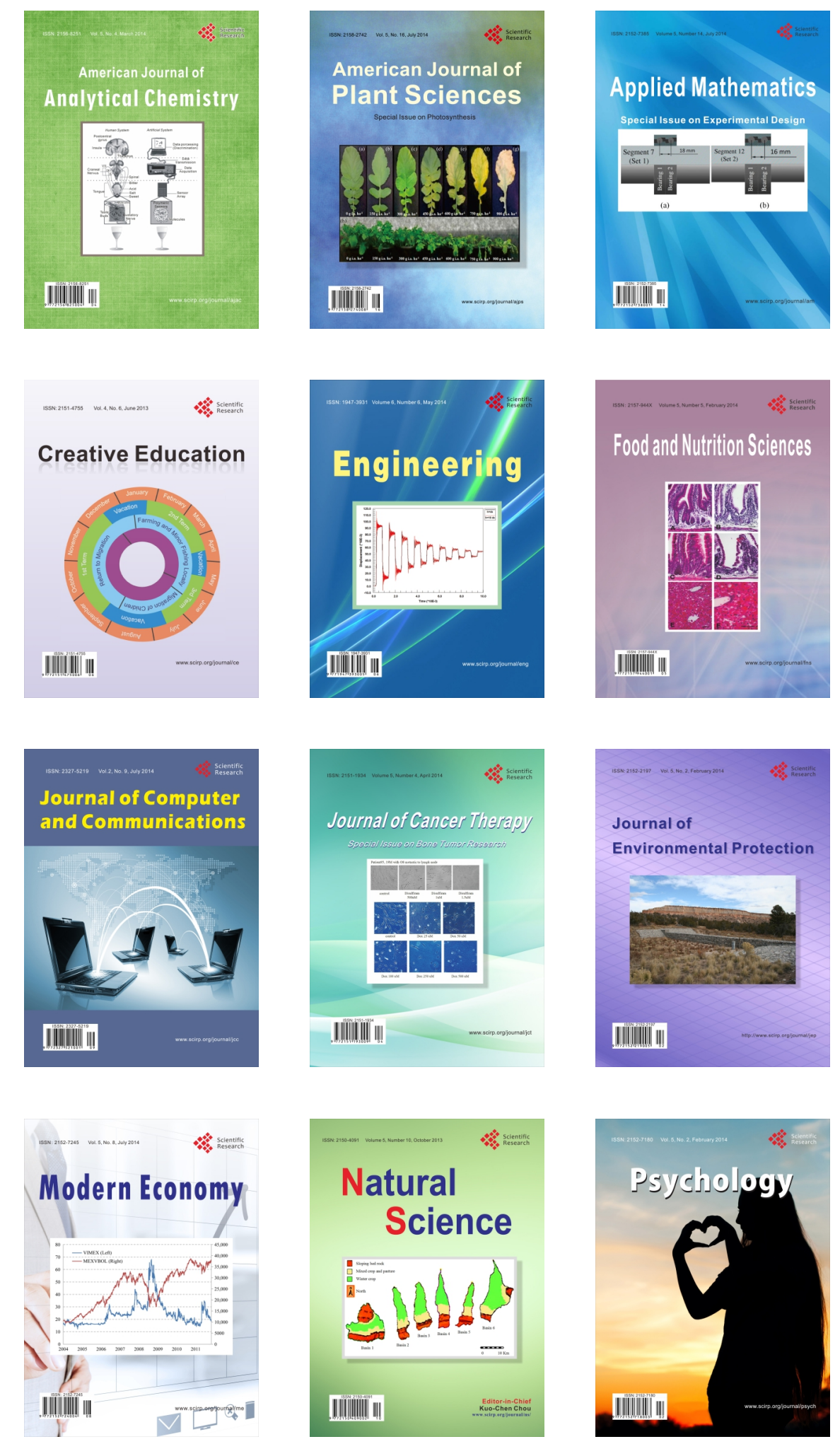